\title{
HUBUNGAN KEYAKINAN DIRI DAN AKTIVITAS PERAWATAN MANDIRI PASIEN HIPERTENSI DI WILAYAH KERJA PUSKESMAS PAHANDUT KOTA PALANGKA RAYA
}

\author{
Alfeus Manuntung \\ Program Studi D-IV Keperawatan \\ Politeknik Kesehatan Kemenkes Palangka Raya \\ alfeusmanuntung@gmail.com
}

\begin{abstract}
ABSTRAK
Hipertensi merupakan salah satu penyebab morbiditas dan mortalitas yang paling sering terjadi di seluruh dunia. Hipertensi disebut juga "pembunuh diam-diam" karena orang dengan hipertensi tidak menampakkan gejala. Orang yang menderita hipertensi biasanya tidak sadar akan kondisinya. Pemahaman dan kemampuan perawatan mandiri pasien hipertensi juga masih rendah. Ketidakpatuhan terhadap perilaku perawatan diri ini dapat berdampak buruk terhadap kesehatan yang dialami penderita hipertensi. Tujuan penelitian ini adalah mengetahui hubungan keyakinan diri dan aktivitas perawatan mandiri pasien Hipertensi di wilayah kerja Puskesmas Pahandut Kota Palangka Raya. Metode penelitian ini yaitu desain penelitian descriptive correlational dengan pendekatan cross sectional study. Teknik pengambilan sampel dalam penelitian ini adalah dengan menggunakan teknik nonprobability sampling yaitu concecutive sampling dengan 50 responden. Pengumpulan data dilakukan selama 2 bulan dengan mengukur tingkat keyakinan diri dan aktivitas perawatan mandiri menggunakan kuesioner. Uji statistik yang digunakan adalah Chi Square. Hasil penelitian menunjukkan bahwa sebagian besar responden tingkat keyakinan dirinya baik yaitu $70 \%$. Sebagian besar responden tingkat aktivitas perawatan mandirinya cukup yaitu 58\%. Hasil uji korelasi Pearson Chi Square keyakinan diri dan aktivitas perawatan mandiri menunjukkan bahwa terdapat hubungan negatif dan tidak signifikan antara keyakinan diri dan aktivitas perawatan mandiri pasien hipertensi. Kesimpulan penelitian ini adalah tidak terdapat hubungan yang signifikan antara keyakinan diri dengan aktivitas perawatan mandiri pasien hipertensi. Penelitian lanjutan dengan disain penelitian klinik acak terkontrol dan jumlah sampel yang besar perlu dilakukan untuk mengembangkan intervensi keperawatan dengan pendekatan perilaku agar dapat meningkatkan keyakinan diri dan perilaku perawatan diri sehingga dapat menurunkan komplikasi hipertensi dan meningkatkan kualitas hidup pasien hipertensi.
\end{abstract}

Kata Kunci: keyakinan diri, aktivitas perawatan mandiri, hipertensi 
The Association Of Self Efficacy And Self Care Activity Of Hypertension Patients In The Working Area Of Puskesmas Pahandut Palangka Raya City

\section{ABSTRACT}

Hypertension is one of the most common causes of morbidity and mortality in worldwide. Hypertension is also called a "silent killer" because people with hypertension often do not show symptoms. People who suffer from hypertension are usually unaware of his condition. The understanding of the patient and the ability of self care behavior of hypertensive patients is also very low. Non-compliance with this self care behavior can adversely affect the health of people with hypertension. The objective of this research is known the association of self efficacy and self care activity of hypertension patients in the working area of Puskesmas Pahandut Palangka Raya City. Methods this research is used descriptive correlational research design with cross sectional study approach. Sampling technique in this research is using nonprobability sampling technique that is concecutive sampling with 50 respondents. Data collection was done for 2 months by measuring self efficacy level and self care activity using questionnaire. The statistical test used is Chi Square test. The results showed that most of the respondents had good efficacy level of 70\%. Most of the respondents sufficient level of self care activity is 58\%. Pearson Chi Square correlation test results self efficacy and self care activities showed that there is a negative and insignificant relationship between self efficacy and self care activities of hypertensive patients. The conclusion of this research is there is no significant relationship between self efficacy with self care activity of hypertension patient. Further research with randomized controlled clinical trial design and a large number of samples should be undertaken to develop nursing interventions with behavioral approaches in order to improve self efficacy and self care behavior so as to reduce hypertension complications and improve the quality of life of hypertensive patients.

Keywords: self efficacy, self care activity, hypertension

\section{PENDAHULUAN}

Hipertensi merupakan salah satu penyebab morbiditas dan mortalitas yang paling sering terjadi di seluruh dunia. Hipertensi disebut juga sebagai "pembunuh diam-diam" karena orang dengan hipertensi sering tidak menampakkan gejala. Orang yang menderita hipertensi biasanya tidak sadar akan kondisinya. Tekanan darah pasien harus dipantau secara teratur karena hipertensi merupakan kondisi seumur hidup begitu penyakit ini diderita (Smeltzer, 2002).

Penyakit hipertensi telah mengakibatkan kematian 9,4 juta warga dunia setiap tahunnya. World Health Organization (WHO) memperkirakan jumlah penderita hipertensi akan terus meningkat seiring dengan jumlah penduduk yang meningkat. WHO juga memproyeksikan sekitar 29 persen warga dunia terkena hipertensi pada tahun 2025 mendatang. Persentase penderita hipertensi saat ini paling banyak terdapat di negara berkembang. Data Global Status Report on Noncommunicable Disesases 2010 dari WHO menyebutkan 40 persen negara ekonomi berkembang memiliki penderita hipertensi, sedangkan negara maju hanya 35 persen. Kawasan Afrika memegang posisi tertinggi penderita hipertensi sebanyak 46 persen, kawasan Amerika menempati posisi terendah dengan 35 persen, sedangkan di kawasan Asia Tenggara 36 persen orang dewasa menderita hipertensi. Penyakit ini telah membunuh 1,5 juta orang setiap tahunnya di kawasan Asia. Hal ini menandakan satu dari tiga orang 
menderita tekanan darah tinggi (Kompas, 2013).

Brashers (2008) menjelaskan bahwa terapi yang adekuat pada penderita hipertensi secara bermakna menurunkan risiko terjadinya penyakit jantung, stroke, dan gagal jantung kongestif. Keberhasilan strategi untuk manajemen tekanan darah tergantung pada manajemen perawatan diri pasien, atau kemampuan dan kemauan pasien untuk mengubah dan mempertahankan perilaku tertentu. Perubahan perilaku meliputi perubahan dalam gaya hidup untuk mengurangi risiko penyakit (misalnya diet, olahraga, berhenti merokok, membatasi konsumsi alkohol), kepatuhan terhadap rejimen pengobatan, monitor tekanan darah, dan kepatuhan terhadap rencana medis tindak lanjut.

Penelitian yang dilakukan oleh Findlow et al., (2012) di Charlotte, USA terhadap 190 responden orang Afrika Amerika dengan metode cross sectional menunjukkan bahwa orang Afrika Amerika merasa yakin bahwa hipertensi merupakan suatu keadaan yang dikelola dan mereka yang memiliki pengetahuan tentang perilaku perawatan diri yang tepat merupakan faktor penting dalam meningkatkan perawatan diri dan mengontrol tekanan darah.

Angka penderita hipertensi di Indonesia mencapai 25,8 persen pada tahun 2013 dengan kisaran usia di atas 15 tahun. Data Riset Kesehatan Dasar 2013 menyebutkan sebanyak sepuluh provinsi mempunyai prevalensi hipertensi pada penduduk umur $>15$ tahun di atas prevalensi nasional, yaitu Bangka Belitung, Kalimantan Selatan, Kalimantan Timur, Jawa Barat, Gorontalo, Sulawesi Tengah, Kalimantan Barat, Sulawesi Selatan, Sulawesi Utara, dan Kalimantan Tengah (Riskesdas, 2013).

Kasus hipertensi di Puskesmas Pahandut Kota Palangka Raya juga menunjukkan peningkatan pada tiga bulan terakhir, yaitu pada bulan
September 2016 dilaporkan kasus baru hipertensi sebanyak 78 orang, bulan Oktober 2016 sebanyak 83 orang, dan bulan Nopember 2016 sebanyak 110 orang (Laporan Surveilans Kasus PTM Puskesmas Pahandut).

Data pendahuluan di Puskesmas Pahandut Kota Palangka Raya menunjukkan bahwa tingkat keterlibatan dalam perawatan diri penderita hipertensi masih relatif rendah. Hal ini kemungkinan terjadi karena penderita mengabaikan atau kurang menyadari karakter penyakit hipertensi. Intensi dan self efficacy penderita hipertensi untuk mengontrol tekanan darah juga masih sangat kurang. Penderita hipertensi cenderung menganggap kesembuhannya permanen ketika tekanan darah sudah kembali normal, padahal sekali divonis hipertensi, penyakit tersebut akan terus membelit tubuh penderita. Pemahaman pasien dan kemampuan penatalaksanaan atau perawatan mandiri (self care behavior) pasien hipertensi juga masih sangat rendah. Ketidakpatuhan terhadap perilaku perawatan diri ini dapat berdampak buruk terhadap kesehatan yang dialami penderita hipertensi.

Berdasarkan latar belakang di atas, maka dirumuskan pertanyaan penelitian yaitu: "Apakah terdapat hubungan antara keyakinan diri dan aktivitas perawatan mandiri pasien hipertensi di wilayah kerja Puskesmas Pahandut Kota Palangka Raya?"

Tujuan penelitian ini yaitu mengetahui hubungan antara keyakinan diri dan aktivitas perawatan mandiri pasien hipertensi di wilayah kerja Puskesmas Pahandut Kota Palangka Raya.

\section{METODE \\ Desain Penelitian}

Penelitian ini menggunakan desain descriptive correlational dengan menggunakan pendekatan cross sectional study. 


\section{Sampel dan Sampling}

Sampel penelitian ini adalah 50 responden di wilayah kerja Puskesmas Pahandut Kota Palangka Raya, dengan menggunakan concecutive sampling .

\section{Instrumen Penelitian}

Instrumen yang digunakan yaitu kuesioner SEMH (Self Efficacy to Manage Hypertension) dan H-SCALE (Hypertension Self Care Activity Level Effects).

\section{Analisis Data}

1) Analisis deskriptif: Analisis ini digunakan untuk memberikan deskripsi data yang disajikan dalam bentuk tabel. Analisis ini digunakan untuk mendeskripsikan karakteristik responden dan variabel penelitian. Variabel yang berbentuk kategorik (jenis kelamin, status perkawinan, pendidikan, pekerjaan, pendapatan, dan lama sakit) atau dikategorisasikan (keyakinan diri dan aktivitas perawatan diri) disajikan dalam bentuk proporsi, sedangkan variabel yang berbentuk numerik (umur) disajikan berupa nilai tendensi sentral dalam bentuk mean, median, modus dan deviasi standar dengan internal consistency (IC) 95\%,

2) Analisis bivariat: Analisis bivariat dalam penelitian ini bertujuan untuk mengetahui apakah ada hubungan yang bermakna antara dua variabel yaitu dependen (keyakinan diri) dan variabel independen (aktivitas perawatan mandiri). Uji Pearson Chi Square digunakan untuk mengetahui hubungan antara keyakinan diri dan aktivitas perawatan mandiri pasien hipertensi. Tingkat kemaknaan (nilai alpha) yang digunakan dalam uji ini adalah sebesar 0,05 dengan CI (95\%).

\section{HASIL}

Data karakteristik responden penelitian meliputi umur, jenis kelamin, status perkawinan, pendidikan, pekerjaan, pendapatan, dan lama sakit Hipertensi pada 50 responden. Distribusi frekuensi tersebut ditunjukkan pada tabel sebagai berikut.

Tabel 1. Distribusi responden berdasarkan umur di Puskesmas Pahandut tahun 2017

\begin{tabular}{cccccc}
\hline No. & Mean & Median & Modus & SD & Min-Maks \\
\hline 1. & 40,38 & 40,00 & 45 & 3,374 & $35-45$
\end{tabular}

Hasil penelitian tentang umur pasien hipertensi menunjukkan bahwa rata-rata umur responden adalah 40,38 tahun.

Tabel 2. Distribusi responden berdasarkan jenis kelamin di Puskesmas Pahandut tahun 2017

\begin{tabular}{clcc}
\multirow{2}{*}{ No } & \multicolumn{1}{c}{ Jenis kelamin } & $\mathrm{f}$ & $\%$ \\
\hline 1. & Laki-laki & 7 & 14 \\
\hline 2. & Perempuan & 43 & 86 \\
\hline \multicolumn{2}{c}{ Jumlah } & 50 & 100
\end{tabular}

Hasil penelitian tentang jenis kelamin pasien hipertensi menunjukkan bahwa sebagian besar responden berjenis kelamin perempuan yaitu $86 \%$. 
Tabel 3. Distribusi responden berdasarkan status perkawinan di Puskesmas Pahandut tahun 2017

\begin{tabular}{llcc}
\hline No & \multicolumn{1}{c}{ Status perkawinan } & f & $\%$ \\
\hline 1. & Belum kawin & 1 & 2 \\
\hline 2. & Kawin & 47 & 94 \\
\hline 3. & Janda/duda & 2 & 4 \\
\hline \multicolumn{2}{r}{ Jumlah } & 50 & 100 \\
\hline
\end{tabular}

Hasil penelitian tentang status perkawinan pasien hipertensi menunjukkan bahwa sebagian besar responden status perkawinannya telah menikah sebanyak $94 \%$.

Tabel 4. Distribusi responden berdasarkan tingkat pendidikan di Puskesmas Pahandut tahun 2017

\begin{tabular}{clccc}
\hline No & Tingkat pendidikan & f & $\%$ \\
\hline 1. & SD & 32 & 64 \\
\hline 2. & SLTP & 7 & 14 \\
\hline 3. & SLTA & 10 & 20 \\
\hline 4. & D-III & 1 & 2 \\
\hline 5. & S-1 & - & 0 \\
\hline & & Jumlah & 50 & 100
\end{tabular}

Ket :*) - : tidak ada

Hasil penelitian tentang tingkat pendidikan pasien hipertensi menunjukkan bahwa sebagian besar responden merupakan tamatan SD yaitu $64 \%$.

Tabel 5. Distribusi responden berdasarkan pekerjaan di Puskesmas Pahandut tahun 2017

\begin{tabular}{clcc} 
No & \multicolumn{1}{c}{ Pekerjaan } & f & $\%$ \\
\hline 1. & PNS & 1 & 2 \\
\hline 2. & Buruh & 3 & 6 \\
\hline 3. & Wiraswasta & 22 & 44 \\
\hline 4. & $\begin{array}{l}\text { Ibu rumah tangga/tidak } \\
\text { bekerja }\end{array}$ & 24 & 48 \\
\hline \multicolumn{1}{c}{ Jumlah } & 50 & 100
\end{tabular}

Hasil penelitian tentang pekerjaan pasien hipertensi menunjukkan bahwa sebagian besar responden merupakan ibu rumah tangga atau tidak bekerja yaitu $48 \%$.

Tabel 6. Distribusi responden berdasarkan pendapatan di Puskesmas Pahandut tahun 2017

\begin{tabular}{cccc}
\hline No & Pendapatan & f & $\%$ \\
\hline 1. & $<\operatorname{Rp~1.000.000,-}$ & 11 & 22 \\
\hline 2. & $\operatorname{Rp~1.000.000,--Rp~5.000.000,-~}$ & 38 & 76 \\
\hline 3. & $>\operatorname{Rp~5.000.000,-}$ & 1 & 2 \\
\hline & Jumlah & 50 & 100 \\
\hline
\end{tabular}

Hasil penelitian tentang pendapatan pasien hipertensi menunjukkan bahwa sebagian besar responden mempunyai pendapatan sebesar Rp 1.000.000,- sampai dengan Rp 5.000.000,- yaitu 76\%. 
Tabel 7. Distribusi responden berdasarkan lama menderita hipertensi di Puskesmas Pahandut tahun 2017

\begin{tabular}{|c|c|c|c|}
\hline No & Lama menderita hipertensi & $f$ & $\%$ \\
\hline 1. & $<1$ tahun & 12 & 44 \\
\hline 2. & $1-2$ tahun & 25 & 50 \\
\hline 3. & $3-5$ tahun & 13 & 26 \\
\hline & Jumlah & 50 & 100 \\
\hline
\end{tabular}

Hasil penelitian tentang lama pasien menderita hipertensi menunjukkan bahwa sebagian besar responden menderita hipertensi selama $1-2$ tahun yaitu $50 \%$.

Tabel 8. Distribusi responden berdasarkan tingkat keyakinan diri di Puskesmas Pahandut tahun 2017

\begin{tabular}{clcc}
\hline No & Tingkat keyakinan diri & $\mathrm{f}$ & $\%$ \\
\hline 1. & Baik & 35 & 70 \\
\hline 2. & Cukup & 14 & 28 \\
\hline 3. & Kurang & 1 & 2 \\
\hline & & 50 & 100
\end{tabular}

Hasil penelitian tentang tingkat keyakinan diri pasien hipertensi menunjukkan bahwa sebagian besar responden tingkat keyakinan dirinya baik yaitu $70 \%$.

Tabel 9. Distribusi responden berdasarkan tingkat aktivitas perawatan mandiri di Puskesmas Pahandut tahun 2017

\begin{tabular}{clcc}
\hline No & $\begin{array}{l}\text { Tingkat aktivitas } \\
\text { perawatan mandiri }\end{array}$ & $\mathrm{f}$ & $\%$ \\
\hline 1. & Baik & 6 & 12 \\
\hline 2. & Cukup & 29 & 58 \\
\hline 3. & Kurang & 5 & 10 \\
\hline & Jumlah & 50 & 100 \\
\hline
\end{tabular}

Hasil penelitian tentang tingkat aktivitas perawatan mandiri pasien hipertensi menunjukkan bahwa sebagian besar responden tingkat aktivitas perawatan mandirinya cukup yaitu $58 \%$.

Tabel 10. Hasil uji Pearson Chi Square keyakinan diri dan aktivitas perawatan mandiri

\begin{tabular}{cc}
\hline Nilai $\mathrm{r}$ & $\mathrm{P}$ \\
\hline 2,485 & 0,647 \\
\hline
\end{tabular}

Hasil uji korelasi Pearson Chi Square keyakinan diri dan aktivitas perawatan mandiri sebagaimana ditunjukkan pada tabel 10 dapat diketahui bahwa terdapat hubungan negatif dan tidak signifikan antara keyakinan diri dan aktivitas perawatan mandiri pasien hipertensi.

\section{PEMBAHASAN}

\section{Keyakinan Diri Pasien Hipertensi}

Hasil penelitian menunjukkan bahwa sebagian besar responden tingkat keyakinan dirinya baik yaitu $70 \%$. Hal ini berhubungan dengan faktor predisposisi yang dimiliki oleh responden yaitu latar belakang pendidikan dan pekerjaan. Semakin tinggi tingkat pendidikan dan pekerjaan akan mempengaruhi keyakinan diri seseorang, selain itu adanya perbedaan dari lamanya menderita hipertensi yaitu rata-rata lama menderita hipertensi juga menyebabkan terjadinya perbedaan self efficacy pada responden. Hal ini sesuai dengan penelitian Findlow (2012) bahwa semakin tinggi tingkat pendidikan dan latar belakang pendidikan, serta semakin lama waktu penerimaan terhadap penyakitnya akan mempengaruhi self efficacy pasien.

Ajzen (2005) menjelaskan bahwa sikap dan perilaku individu terhadap suatu 
hal dipengaruhi oleh tiga faktor latar belakang, yakni personal, sosial, dan informasi. Faktor personal adalah sikap umum seseorang terhadap sesuatu, sifat kepribadian (personality traits), nilai hidup (values), emosi, dan kecerdasan yang dimilikinya. Faktor sosial antara lain adalah usia, jenis kelamin (gender), etnis, pendidikan, penghasilan, dan agama. Faktor informasi adalah pengalaman, pengetahuan dan paparan pada media. Perilaku dilakukan karena individu mempunyai minat atau keinginan untuk melakukannya. Minat dan keinginan pasien adalah hal yang penting, pasien perlu menyadari bahwa merekalah yang mengontrol kehidupannya, bukan orang lain, dan mereka yang bertanggung jawab hasil dari perbuatannya dan setiap pasien mempunyai kemampuan untuk berubah.

Hasil penelitian ini juga sesuai dengan teori Health Belief Model (HBM) di dalam Edberg (2010) bahwa seseorang yang telah mendapatkan informasi dan keterampilan terkait dengan penyakitnya akan mempunyai persepsi yang baik pula terhadap penyakitnya dan akan membentuk dan memperkuat self efficacy seseorang sebelumnya.

Hasil penelitian yang dilakukan oleh Walker (2007) menyatakan bahwa terdapat hubungan yang positif antara persepsi dan self efficacy pasien, yaitu jika persepsi baik, maka self efficacy meningkat. Hal ini juga didukung oleh Bandura (1994) yang menjelaskan bahwa self efficacy seseorang dipengaruhi oleh empat faktor, yaitu performance accomplishment, vicarious experience, verbal persuasion, dan emotional arousal. Self efficacy tersebut dapat diperoleh, diubah, atau ditingkatkan melalui salah satu atau kombinasi empat faktor tersebut. Performance accomplishment merupakan suatu pengalaman atau prestasi yang pernah dicapai oleh individu tersebut di masa lalu, vicarious experience merupakan pengalaman yang diperoleh dari orang lain, verbal persuasion merupakan persuasi yang dilakukan oleh orang lain secara verbal maupun oleh dirinya sendiri (self talk) yang dapat mempengaruhi seseorang untuk bertindak atau berperilaku, dan emotional arousal yang merupakan pembangkitan emosi positif sehingga individu mempunyai keyakinan untuk melakukan tindakan tertentu. Keempat faktor tersebut akan mempengaruhi persepsi seseorang terhadap penyakit dan pengelolaannya yang meliputi persepsi pasien tentang kerentanan (susceptible), keparahan (severity), manfaat dari tindakan yang dilakukan, persepsi tentang sedikitnya hambatan dan adanya petunjuk dan arahan dari tenaga kesehatan dalam penatalaksanaan penyakitnya.

Pengetahuan dan dukungan informasi yang cukup tentang penyakit hipertensi dapat menimbulkan kesadaran dan sikap yang positif untuk perawatan hipertensi. Sikap empati merupakan ciri penting bagi membangun keyakinan dan kepercayaan responden, selain itu kerja sama antara responden dan perawat juga mampu membuat proses pertukaran pikiran dapat dilakukan dengan bimbingan. Pertukaran pikiran dan emosi tersebut bisa membuat responden merasakan perasaannya. Bentuk interaksi yang terjadi dalam suasana yang kondusif juga turut menyumbang ke arah peningkatan sikap menghargai diri sendiri.

\section{Aktivitas Perawatan Mandiri Pasien Hipertensi}

Hasil penelitian menunjukkan bahwa sebagian besar responden tingkat aktivitas perawatan mandirinya cukup yaitu $58 \%$. Green dalam Notoatmodjo (2003) menjelaskan bahwa perilaku kesehatan dipengaruhi oleh tiga faktor, yaitu faktor predisposisi (predisposising factors), faktor pemungkin (enabling factors), dan faktor penguat (reinforcing factors). Faktor predisposisi meliputi karakteristik responden, pengetahuan, sikap, keyakinan, kepercayaan, nilai, dan tradisi. Seseorang dengan pengetahuan yang cukup tentang perilaku perawatan hipertensi, maka secara langsung akan bersikap positif dan menuruti 
aturan perawatan disertai munculnya keyakinan untuk sembuh. Faktor pemungkin meliputi ketersediaan sarana kesehatan, ketercapaian sarana, keterampilan yang berkaitan dengan kesehatan. Lingkungan yang jauh atau jarak dari pelayanan kesehatan memberikan kontribusi rendahnya perilaku perawatan pada penderita hipertensi. Faktor penguat meliputi sikap dan praktik petugas kesehatan dalam pemberian pelayanan kesehatan, sikap dan praktik petugas lain seperti tokoh masyarakat, tokoh agama, dan keluarga. Dukungan petugas kesehatan sangat membantu dan sangat besar artinya bagi seseorang dalam melakukan perawatan hipertensi, sebab petugas adalah yang merawat dan sering berinteraksi, sehingga pemahaman terhadap kondisi fisik maupun psikis lebih baik, dengan sering berinteraksi akan sangat mempengaruhi rasa percaya dan menerima kehadiran petugas bagi dirinya, serta motivasi atau dukungan yang diberikan petugas sangat besar artinya terhadap ketaatan pasien untuk selalu mengontrol tekanan darahnya secara rutin. Dukungan keluarga juga sangat berperan dalam menentukan cara asuhan yang diperlukan oleh anggota keluarga yang menderita hipertensi sehingga mereka merasa tidak sendiri dalam menghadapi penyakitnya karena penyakit hipertensi merupakan penyakit seumur hidup dan perawatannya pun seumur hidup.

Notoatmojo (2010) menjelaskan bahwa perilaku ketaatan pada individu sangat dipengaruhi oleh beberapa faktor yaitu pengetahuan, sikap, ciri individual, dan partisipasi. Pengetahuan merupakan hal yang sangat berpengaruh terhadap terbentuknya perilaku seseorang. Pengetahuan pasien tentang perawatan pada penderita hipertensi yang rendah dapat menimbulkan kesadaran yang rendah pula sehingga mempengaruhi penderita hipertensi dalam mengontrol tekanan darah, kedisiplinan pemeriksaan yang akibatnya dapat terjadi komplikasi lanjut. Perawatan mandiri pasien sangat tergantung pada pendidikan kesehatan yang diperoleh, pendayagunaan dan kemampuan monitoring terhadap manajemen perawatan diri sehingga membantu pasien hipertensi dalam mengubah perilakunya secara signifikan untuk meningkatkan self management sehingga hasil yang diharapkan berupa pencegahan komplikasi dan peningkatan kualitas hidup dapat tercapai.

Brashers (2008) menjelaskan bahwa terapi yang adekuat secara bermakna dapat menurunkan risiko terjadinya penyakit jantung, stroke, dan gagal jantung kongestif. Keberhasilan terapi bergantung pada pendidikan pasien, tindak lanjut yang cermat, dan pembahasan strategi secara berulang bersama pasien. Keterlibatan pasien dalam perencanaan perawatan memberikan pasien perasaan kontrol diri yang berkelanjutan, memperbaiki keterampilan koping, dan dapat meningkatkan kerja sama dalam regimen terapeutik. Pasien yang merasa yakin bahwa hipertensi merupakan suatu keadaan yang dikelola dan pasien yang memiliki pengetahuan tentang perilaku perawatan diri yang tepat merupakan faktor penting dalam meningkatkan perawatan diri hipertensi dan kontrol tekanan darah. Pengetahuan yang rendah akan berdampak pada kemampuan pasien dalam pengelolaan hipertensi secara mandiri (self care behavior) sehingga mengakibatkan tingginya angka morbiditas dan mortalitas, serta komplikasi yang dialami pasien.

Inti penatalaksanaan hipertensi adalah pencegahan pada individu yang memiliki tekanan darah tinggi dengan mengatur pola hidup sehat untuk mengurangi komplikasi hipertensi meliputi manajemen berat badan, menghindari alkohol, berhenti merokok, dan modifikasi diet. Peningkatan kemampuan perawatan diri pasien (self care behavior) tidak terlepas dari proses belajar pasien selama dilakukan intervensi. Setiap perilaku manusia itu merupakan hasil dari proses belajar (pengalaman) dalam merespons berbagai stimulus dari lingkungannya dan dalam proses belajar untuk menghasilkan 
perilaku tersebut, aspek kognitif memiliki peranan penting terutama dalam mempertimbangkan berbagai tindakan yang hendak dilakukan, menentukan pilihan tindakan, dan mengambil keputusan tindakan perilakunya.

\section{Hubungan antara Keyakinan Diri dan Aktivitas Perawatan Diri pada Pasien Hipertensi}

Hasil uji korelasi Pearson Chi Square keyakinan diri dan aktivitas perawatan mandiri menunjukkan bahwa terdapat hubungan negatif dan tidak signifikan antara keyakinan diri dan aktivitas perawatan mandiri pasien hipertensi. Hal ini bertolak belakang dengan hasil penelitian yang dilakukan oleh Findlow (2012) menunjukkan hubungan positif antara self efficacy dan self care behavior sehingga adanya peningkatan self efficacy juga akan diikuti dengan peningkatan self care behavior.

Bandura (1994) menjelaskan bahwa self efficacy akan mempengaruhi empat proses dalam diri manusia, yaitu cara individu berpikir (kognitif), perasaan (afektif), motivasional, dan seleksi terhadap perilaku perawatan yang dipilih oleh individu. Self efficacy akan mempengaruhi cara seseorang untuk berpikir, perasaan, motivasi, dan penampilan yang ditunjukkan individu. Motivasi seseorang untuk menunjukkan perilaku tertentu tergantung pada kemampuan individu mengevaluasi self efficacy yang dimilikinya. Self efficacy individu yang semakin baik akan memudahkan individu dalam memecahkan masalah. Individu yang meyakini bahwa dia mampu melakukan suatu perilaku tertentu akan melakukan perilaku tersebut, sedangkan individu dengan self efficacy yang kurang cenderung untuk tidak melakukan perilaku tersebut atau menghindarinya. Individu dengan self efficacy yang baik akan lebih mudah mengadopsi perilaku baru.

Hasil penelitian ini bertolak
belakang dengan pendapat yang
disampaikan Bandura (1994) yang

menyatakan bahwa self efficacy merupakan prediktor yang paling efektif dalam menilai perubahan perilaku seseorang. Individu dengan self efficacy yang baik akan mempunyai kemampuan kontrol diri yang kuat dalam menghadapi ancaman, mempunyai masalah yang lebih sedikit dan lebih mudah pulih dengan cepat. Perilaku seseorang dipengaruhi oleh persepsi individu terhadap tiga hal, yaitu persepsi tentang tingkat risiko, yang diikuti oleh harapan bahwa perilaku akan menurunkan risiko dan harapan bahwa mereka mampu untuk melakukan perubahan perilaku. Tiga persepsi tersebut secara bersama-sama akan mempengaruhi intensi perilaku dan usaha untuk melakukan perubahan perilaku, dan mempertahankan perilaku baru yang sudah dilakukan.

Hasil penelitian yang dilakukan Bosworth (2009) bahwa tingkat self efficacy yang baik dapat menyebabkan peningkatan self management untuk memperbaiki kontrol hipertensi. Hasil penelitian Findlow (2012) yang menyatakan bahwa self efficacy dapat digunakan sebagai prediktor untuk mengetahui kepatuhan pasien dalam self care behavior. Pasien dengan kepatuhan yang kurang mempunyai self efficacy yang kurang juga. Pasien hipertensi dengan self efficacy yang baik menunjukkan ketaatan dalam manajemen hipertensi daripada pasien yang self efficacy-nya kurang dan nilai self efficacy berhubungan dengan perilaku spesifik dalam penatalaksanaan hipertensi, seperti manajemen berat badan, diet, dan pengobatan.

Self efficacy yang baik akan membuat individu merasa mampu untuk melakukan perilaku perawatan mandiri (self care behavior) sehingga dapat menurunkan komplikasi hipertensi dan meningkatkan kualitas hidupnya. Perilaku yang didasari oleh pengetahuan dan sikap positif, maka perilaku tersebut akan bersifat langgeng. Pengetahuan pasien yang semakin meningkat tentang hipertensi akan mengarah pada kemajuan berpikir tentang 
perilaku yang baik sehingga bisa berpengaruh terhadap terkontrolnya tekanan darah. Perilaku yang baik tersebut bisa dalam hal perencanaan makan, misalnya diet rendah garam, mengurangi konsumsi lemak hewani, kacang tanah, makanan yang berkolesterol tinggi dan mengandung alkohol, dalam hal olah raga penderita selalu rutin jalan pagi dan senam pagi. Hal inilah yang dapat membantu mengontrol tekanan darah.

Keterbatasan penelitian ini adalah tidak menggunakan teknik randomisasi dalam teknik pengambilan sampel, selain itu pengisian kuesioner dipengaruhi oleh pemahaman dan daya ingat responden terhadap dukungan yang diterima dan kualitas hidup yang dirasakan.

\section{SIMPULAN}

Hasil penelitian menunjukkan bahwa sebagian besar responden tingkat keyakinan dirinya baik yaitu $70 \%$. Hasil penelitian menunjukkan bahwa sebagian besar responden tingkat aktivitas perawatan mandirinya cukup yaitu 58\%. Hasil uji korelasi Pearson Chi Square keyakinan diri dan aktivitas perawatan mandiri menunjukkan bahwa terdapat hubungan negatif dan tidak signifikan antara keyakinan diri dan aktivitas perawatan mandiri pasien hipertensi. Kesimpulan dari penelitian ini adalah tidak terdapat hubungan yang signifikan antara keyakinan diri dengan aktivitas perawatan mandiri pasien hipertensi.

\section{DAFTAR PUSTAKA}

Ajzen, I., 2005. Attitude, personality, \& behavior. Open University Press.

Arch, J.J., Ayers, C.R., Baker, A. Almklov, E., Dean, D.J., \& Craske M.G., 2013. 'Randomized clinical trial of adapted mindfulness-based stres reduction versus group cognitive behavioral therapy for heterogeneous anxiety disorders'. Behaviour Research and Therapy 51 (2013) 185e196. Diakses dari http://www.sciencedirect.com/ pada tanggal 5 Oktober 2017.

Badan Penelitian dan Pengembangan Kesehatan Kemenkes R.I., 2013. Laporan hasil riset kesehatan dasar (Riskesdas) 2013. Kementerian Kesehatan Republik Indonesia, Jakarta.

Bandura, A., 1994. 'Self-efficacy: toward a unyfying theory of behavioral change'. Psychological Review 1977, vol. 84. no. 2. 191-215. Diakses dari http://www.ou.edu/cls/online/ pada tanggal 20 Oktober 2017.

Bandura, A., 1994. 'Self-efficacy. in v. s. ramachaudran (ed.), encyclopedia of human behavior'. New York: Academic Press, vol. 4, pp. 71-81. Diakses dari http://www.des.emory.edu/mfp/Ban Ency.html pada tanggal 20 Oktober 2017.

Bappeda Kota Palangka Raya, 2014. 'Selayang pandang Kota Palangka Raya', 11 Pebruari 2014. Diakses dari

http://www.bappeda.palangkaraya. go.id/ pada tanggal 12 Januari 2017.

Bosworth, H.B., Olsen, M.K., Grubber J.M., Neary A.M., RN, Orr M.M., Powers B.J., Adams M.B., Svetkey L.P., Reed S.D., Li, Yanhong, Dolor R.J., Oddone E.Z., 2009. 'Two Self-management Interventions to Improve Hypertension Control'. Ann Intern Med. 2009;151:687-695. Diakses dari http://www.sciencedirect.com/ pada tanggal 5 Oktober 2017.

Brashers, Valentina L., 2008. Aplikasi klinis patofisiologi: pemeriksaan dan tanggal 21 Oktober 2017.

Dinas Kesehatan Kota Palangka Raya, 2015. Profil Kesehatan Kota Palangka Raya, 2015.

Dinas Kesehatan Kota Palangka Raya, 2015. 'UPTD Puskesmas Pahandut'. Diakses dari 
http://www.dinkes.palangkaraya.go .id/ pada tanggal 12 Januari 2017.

Edberg, M., 2010. Buku ajar kesehatan masyarakat: teori sosial dan perilaku. Alih bahasa: Anwar, dkk, Jakarta: EGC.

Findlow, J.W. \& Seymour, R.B., 2011. 'Prevalence rates of hypertension self-care activities among African Americans'. J Natl Med Assoc. 2011 June; 103(6): 503-512. Diakses dari http://www.ncbi.nlm.nih.gov/pmc/ pada tanggal 8 Januari 2017.

Findlow, J.W., Seymour, R.B., \& Brunner, H.L.R., 2012. 'The association between self-efficacy and hypertension self-care activities among African American adults'. $J$ Community Health. 2012 Feb;37(1):15-24. doi: 10.1007/s10900-011-9410-6.

Diakses

dari http://www.ncbi.nlm.nih.gov/ pada tanggal 7 Januari 2017.

Lemeshow, S., Hosmer, D.W., Klar, J. \& Lwangsa, S.K., 1990. Adequacy of sample size in health studies. World Health Organization.

Notoatmodjo, S., 2010. Ilmu perilaku kesehatan. Jakarta: Rineka Cipta.

Nursalam, 2003. Konsep dan penerapan metodologi penelitian ilmu keperawatan: pedoman skripsi, tesis, dan instrumen penelitian. Jakarta: Salemba Medika.

Smeltzer, Suzanne C., 2002. Buku ajar keperawatan medikal bedah: Brunner \& Sudarth. edisi 8. vol 2. Alih bahasa: Kuncara, dkk. Jakarta: EGC.

Widiyani, Rosmha, 2013. 'Penderita hipertensi terus meningkat', 5 April 2013. Diakses dari http://www.kompas.com/ pada tanggal 1 Januari 2017. 